\title{
Community empowerment in leading pesantren: A research of Nyai's leadership
}

\author{
Samsu Samsu ${ }^{1}$, Martin Kustati ${ }^{2}$, David D. Perrodin ${ }^{3}$, Mahyudin Ritonga ${ }^{4}$, Muhammad Kosim ${ }^{5}$, \\ Rusmini Rusmini ${ }^{6}$, Suwendi Suwendi ${ }^{7}$ \\ ${ }^{1,6}$ Universitas Islam Negeri Sulthan Thaha Saifuddin, Jambi, Indonesia \\ ${ }^{2,5}$ Universitas Islam Negeri Imam Bonjol Padang, West Sumatra, Indonesia \\ ${ }^{3}$ Institute for Population and Social Research, Mahidol University, Thailand \\ ${ }^{4}$ Muhammadiyah University of West Sumatera, Indonesia \\ ${ }^{7}$ Universitas Islam Negeri Syarif Hidayatullah, Jakarta, Indonesia
}

\begin{tabular}{l} 
Article Info \\
\hline Article history: \\
Received Mar 3, 2021 \\
Revised Aug 20, 2021 \\
Accepted Sep 10, 2021 \\
\hline Keywords: \\
Boarding schools \\
Community empowerment \\
Character \\
Nyai's leadership
\end{tabular}

\begin{abstract}
Leadership is one of the essential factors that can influence community involvement in realizing the character of male and female students in the pesantren (Islamic boarding schools) in Jambi, Indonesia. This study proposed Nyai's (female religious leaders in the pesantren) charismatic, economic, and social responsibility leadership models in the context of community empowerment (CE). This quantitative research aimed to determine the contribution of Nyai's leadership models to CE. The data from the questionnaire were analyzed using path and flowchart analysis. The results showed that the three Nyai's leadership models in this study influenced and contributed to CE to support the pesantren's activities and programs. This study recommended adopting the three Nyai's leadership models in empowering the community in the pesantren.
\end{abstract}

This is an open access article under the CC BY-SA license.

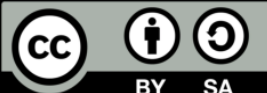

\section{Corresponding Author:}

Samsu Samsu

Faculty of Islamic Education and Teacher Training

Universitas Islam Negeri Sulthan Thaha Saifuddin

Jambi, 36361, Indonesia

Email: samsu@uinjambi.ac.id

\section{INTRODUCTION}

Women's leadership has been a passionate topic in Indonesia, where women are still considered weak and unworthy leaders in both public and domestic sectors [1]-[3]. Nyai (female religious leaders in the pesantren/Islamic boarding school) in the literature about women's leadership is an interesting issue to study, especially since it is related to the sensitive topic of 'women' in leadership roles within the Islamic religion. The assumption that men are leaders and women should take care of the domestic sector is still controversial in the Islamic religion. This opinion was reinforced by Cerrato and Cifre [4], who stated that the role of humans was divided into two areas: public (al-wilayah al-'amah) and domestic (al-wilayah al-khashah) sectors. Cerrato and Cifre asserted that the public sector is generally the place of men, whereas the household sector is the place of women. This means that there are positives and negatives regarding women's leadership in pesantren. This debate is interesting since, in the leadership of a pesantren (Islamic boarding schools) with a strong Islamic tradition, it should be led by a Kyai (a male religious expert or leader in Islam). In fact, the pesantren of Ainul Yaqin Jambi is led by a Nyai [5].

There are two terms for women's leadership in the pesantren: Nyai and Badal Nyai. Nyai is a female family member closest to Kyai, while Badal Nyai is a young Nyai who takes on a female teacher's role. 
Hidayah and Arifi noted that Nyai is the usual term for a Kyai's wife. Kyai and Nyai are sources of advice for the santri (individuals who practice a more conventional version of Islam) at the pesantren [6]. The personal relations between the santri and Kyai and Nyai are united by a sense of religion so that karamah (honor or regard from God) and barakah (a blessing power) are developed.

Previous studies related to Nyai's leadership focused more on the leadership style. Researchers have yet to attempt to link Nyai's leadership to community empowerment. Rahayu and Faraz discussed the type of Nyai's leadership to preserve the Kitab Kuning (the traditional set of the Islamic manuscripts), as evidenced by the dominance of charismatic and democratic types. Rahayu and Faraz concluded that Nyai's leadership style prioritized work and authoritarian orientation [7]. This study suggests, in agreement with Hidayah and Arifi [6], that the leadership of pesantren should be fixated on the religious leaders and more creative development of the pesantren economic program.

Marks and Printy discussed some dominant factors that influence women's leadership: social, cultural, and political supports [3]. Hernawati stated that "women leaders on average manifest values, effective leadership styles... Because of the remaining prejudicial barriers, women face challenges as leaders that men do not face, especially in settings where female leaders are nontraditional" [8].

Hernawati also showed immense attractiveness in Nyai's leadership because this leadership model adopts a charismatic leadership style [8]. Meanwhile, Muflichah and Muhaemin indicated that Nyai's leadership style was more like a charismatic leadership style characterized by always teaching goodness and worship [9], [10]. Nyai also demonstrates a collective leadership pattern based on modern management rules by delegating authority.

Budiwiranto and Elfira, in contrast, described the contribution and position of Nyai [11], [12]. They concluded that many Nyais already had leadership roles in the pesantren. Furthermore, with the responsiveness, determination, and creativity of Nyai's leadership, they built religious authority and the pesantren's development. Nyai's works also refer to the awareness of feminism by reflecting on personal experiences and efforts as women and scholars. This belief has roots in the pesantren tradition of empowerment, independence, and tolerance of diversity. Chusniyah, et al. explained that Nyai's leadership roles include domestic and public leadership roles [13]. Hidayah and Arifi indicated that Nyai's charismatic leadership type dominated Nyai's leadership [6]. There is rare research that relates Nyai's leadership to community empowerment especially related to charismatic, economic, and social responsibility models, not is there any such research that encourages such a link as an essential part that has to be built by Nyai as a leader in a pesantren. This is important because a pesantren, as an educational institution, is responsible for religious education and empowering the community and students to expand the students' capacity. The term community empowerment refers to the involvement of people outside of the pesantren to initiate improvement of the pesantren's social situation and conditions. Thus, community empowerment is interpreted as an effort to encourage the community to help develop the pesantren. The focus of the study is Nyai's leadership concerning community empowerment. The concern of this research is to raise the lifeblood of the pesantren. Therefore, Nyai's leadership is the primary key to this empowerment. The purpose of the study is to determine the contribution of Nyai's leadership to community empowerment.

\section{LITERATURE REVIEW}

The leadership of women normatively has substantial legitimacy, theologically, philosophically, and legally, for example, the Universal Declaration of Human Rights, which states that women should be granted the freedom to choose and be elected as leaders. Laws of the Republic of Indonesia UU RI No.7/1984, which concerns eliminating all forms of discrimination against women, and Laws of the Republic of Indonesia (UU RI) No. 39/1999 which involves human rights, has guaranteed women's representation in the Legislative, Executive, and Judiciary branches. Presidential Instruction No.9/2000 on gender mainstream requires all national development policies and programs to be designed based on gender [14].

Empowerment is expected to be the primary goal of developing the pesantrens. Empowerment encourages and attracts all participation of pesantren residents to change the pesantren area so that it can be recognized from the outside. Community empowerment has proven to be a practical approach to solving various community problems [15], [16]. Cattaneo and Chapman defined empowerment as an effort to build relationships of strength and competence of a person, use nature, and take proactive action on change and social policies [17]. They further said that community empowerment is developing and strengthening an individual's ability to participate in sustainable community development. Indicators of growth in people's capacity and motivation to solve problems and their ability to make decisions freely according to their choices. Previous studies also defined community empowerment as a form of tangible assistance and adequate knowledge for unity at the initial stage of introduction [16], [18]. The model suggested by Iskandarini in community empowerment by expanding leadership attention to the community is social capital 
development based on collaboration or cooperation [19]. A community is a group of people who may be linked spatially and share common interests, concerns, and identities [20].

In the empowerment paradigm, Huis, et al. stated that society is empowered when it has strength, including power, cognitive, psychological, economic, and political [21]. From this empowerment paradigm, previous studies stated that psychologically charismatic leadership considers examples of behavioral models through the words and deeds of the leader to be a key determinant of charismatic relationships [22], [23]. Cogliser, et al. likewise said that the spread of responsibility and member activities would stimulate a collective performance level [24].

Based on the paradigm of empowerment, it can be concluded that community empowerment is more influenced by charisma, economic factors, and social responsibility built by Nyai as a leader in a pesantren. This factor then allows a pesantren to develop. Thus, these factors become a model of leadership in community empowerment. Pesantren with weak empowerment can be empowered through the leadership model offered, increased knowledge, and participation to develop. After that, the empowerment process will continue until it achieves sustainable empowerment, namely, developing a pesantren, as in the theoretical framework adapted from Sianipar, et al. [25] as seen in Figure 1.

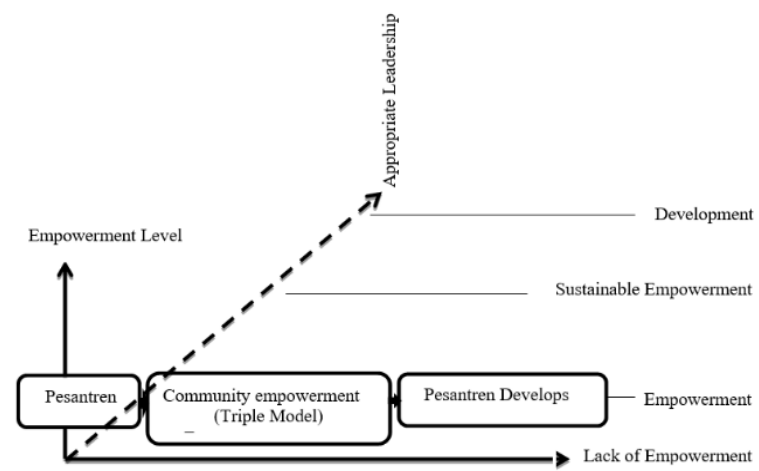

Figure 1. Stages of the empowerment process

Regarding pesantren, many experts who define pesantren generally agree that a pesantren is a place for male and female students to live and conduct Islamic religious studies [26], [27], for example, some experts stated that technically the pesantren is a residence for students who are thoroughly learning. He added that there are also pesantren whose students do not live in the dormitories but live in their respective homes because they are santri kalong (local residents who only participate in study at the pesantren). Thus, a pesantren can be understood as a place used by Kyai, Nyai, and santri in carrying out their daily activities.

Apart from the pesantren as a residence for students [1], [26], [27], the pesantren tradition has a great tradition in Indonesia in the field of Islamic teaching, which aims to transmit traditional Islam values. In the era of globalization, a pesantren must modify the pesantren's objectives with the needs of society as institutions for empowering and fostering people. Previous researchers likewise stated that at the end of the 20th century, the establishment of the pesantren is different from the past [26]-[30]. In the past, a pesantren stood at the same time as the forerunner to establishing local villages. Now, the pesantren is established in a village or community environment that is already busy or advanced.

Ma'arif, regarding leadership, stated that women have the same responsibility as men in building the society, nation, and the world [31]. With many intellectual, social, emotional, and professional skills and abilities possessed by women, they can contribute to the nation's future civilization. He states at least three roles and functions of women: the natural, economic, and social roles. Natural roles refer to reproductive roles such as pregnancy, childbirth, breastfeeding, or roles that are not worth money. The economic role is understood as a productive role (multiple roles) where women work in the household (unpaid) or outside the home (paid). The social role is interpreted as the role of women in a social context with various roles in various sectors and success in managing the household.

In the pesantren, Nyai is the central figure. She has the authority and is the center of policy and change in the pesantren. Therefore, any changes or reforms made in the pesantren should come from the pesantren's willingness. In this case, Nyai plays an important role. Thus, the main characteristics of Nyai's appearance are her charisma, economic prowess, and social responsibility. 


\section{RESEARCH METHOD}

This study was conducted in boarding school Ainul Yakin in the Jambi Province, Indonesia using a mixed-methods design. A quantitative method was used in this study [32], [33]. In this study, the primary quantitative data was obtained using a questionnaire to explore variables with a partial and simultaneous influence on community empowerment. The preliminary data were analyzed using path analysis with SPSS 20.0. The supporting data are the charismatic, economic, and social responsibility characteristics of Nyai's leadership model. The data were analyzed using flowchart analysis [34]. This mixed-methods approach was adopted to understand better the forms of empowerment practiced by Nyai in the pesantren. The sample of this study was 75 participants that consist of one Nyai, 15 teachers and six students at the pesantren, and 53 people of the community around the pesantren.

\section{RESULTS AND DISCUSSION}

\subsection{Results}

The proposed hypotheses are: i) Charismatic model $\left(\mathrm{X}_{1}\right)$ has a direct influence on $\mathrm{CE}(\mathrm{Y})$; ii) Economic model $\left(\mathrm{X}_{2}\right)$ has a direct influence on $\mathrm{CE}(\mathrm{Y})$; iii) Charismatic model $\left(\mathrm{X}_{1}\right)$ and economic model $\left(\mathrm{X}_{2}\right)$ have a simultaneous direct influence on $\mathrm{CE}(\mathrm{Y})$; iv) Charismatic model ( $\left.\mathrm{X}_{1}\right)$ partially and simultaneously has a direct influence on social responsibility $\left(\mathrm{X}_{3}\right)$; v) Economic model $\left(\mathrm{X}_{2}\right)$ has a direct influence on social responsibility $\left(\mathrm{X}_{3}\right)$; vi) Charismatic model $\left(\mathrm{X}_{1}\right)$ and economic model $\left(\mathrm{X}_{2}\right)$ simultaneously have a direct influence on social responsibility $\left(\mathrm{X}_{3}\right)$; vii) Social responsibility $\left(\mathrm{X}_{3}\right)$ have a direct influence on $\mathrm{CE}(\mathrm{Y})$; (viii) Charismatic model $\left(\mathrm{X}_{1}\right)$, economic model $\left(\mathrm{X}_{2}\right)$, and social responsibility $\left(\mathrm{X}_{3}\right)$ simultaneously have a direct influence on $\mathrm{CE}(\mathrm{Y})$; and ix) Charismatic model $\left(\mathrm{X}_{1}\right)$ has a direct influence on community empowerment $(\mathrm{Y})$ through social responsibility $\left(\mathrm{X}_{3}\right)$, and economic model $\left(\mathrm{X}_{2}\right)$ have a direct influence on $\mathrm{CE}$ $(\mathrm{Y})$ through social responsibility $\left(\mathrm{X}_{3}\right)$. Statistical analysis was performed through correlation, regression, and path analysis.

The statistical analysis, followed by qualitative analysis, was carried out to provide meaning and conclusions from the data on Nyai's leadership model in the pesantren; they are charismatic, economic, and social responsibility models. The results are shown by descriptive analysis and hypothesis testing of the CE variable data $(\mathrm{Y})$, the variable data of charismatic model $\left(\mathrm{X}_{1}\right)$, the variable data of economic model $\left(\mathrm{X}_{2}\right)$, and the variable data of social responsibility model $\left(\mathrm{X}_{3}\right)$. The findings can be concluded in Table 1 .

Table 1. Analysis of descriptive research

\begin{tabular}{cccccc}
\hline No & Description & $\mathrm{X}_{1}$ & $\mathrm{X}_{2}$ & $\mathrm{X}_{3}$ & $\mathrm{Y}$ \\
\hline 1 & Minimum & 86 & 89 & 60 & 74 \\
2 & Maximum & 140 & 139 & 158 & 138 \\
3 & Mean & 110.44 & 112.1867 & 102.2933 & 101.4 \\
4 & Median & 108 & 111 & 100 & 101 \\
5 & Mode & 95 & 100 & 98 & 101 \\
6 & Std. deviation & 12.9586 & 12.57915 & 22.21989 & 16.3674 \\
7 & Variance & 167.925 & 158.235 & 493.724 & 267.892 \\
8 & Std. error of mean & 1.49633 & 1.45251 & 2.56573 & 1.88994 \\
9 & Range & 54 & 50 & 98 & 64 \\
10 & Summary & 8283 & 8414 & 7672 & 7605 \\
\hline $\mathrm{X}_{1}=$ charismatic model; $\mathrm{X}_{2}=$ economic model; $\mathrm{X}_{3}=$ social responsibility; Y=community empowerment $(\mathrm{CE})$
\end{tabular}

There were five hypotheses in this study. First, the social responsibility variable $\left(\mathrm{X}_{3}\right)$ to $\mathrm{CE}(\mathrm{Y})$ is $70.70 \%$. Second, the charismatic variable $\left(\mathrm{X}_{1}\right)$ to $\mathrm{CE}(\mathrm{Y})$ is $59.00 \%$. Then, the charismatic variable $\left(\mathrm{X}_{1}\right)$ on social responsibility $\left(\mathrm{X}_{3}\right)$ is $40.70 \%$. Next, the economic variable $\left(\mathrm{X}_{2}\right)$ through $\mathrm{CE}(\mathrm{Y})$ is $32.70 \%$. The economic variable $\left(\mathrm{X}_{2}\right)$ through social responsibility $\left(\mathrm{X}_{3}\right)$ is $25.90 \%$. Meanwhile, simultaneously, it is known from the statistical analysis that the variables which gave the most significant influence are: Charismatic $\left(\mathrm{X}_{1}\right)$, economic $\left(\mathrm{X}_{2}\right)$, and social responsibility $\left(\mathrm{X}_{3}\right)$ variables to $\mathrm{CE}(\mathrm{Y})$ is $74.50 \%$; charismatic $\left(\mathrm{X}_{1}\right)$ and economic $\left(\mathrm{X}_{2}\right)$ through $\mathrm{CE}(\mathrm{Y})$ variables is $66.80 \%$, and charismatic $(\mathrm{X} 1)$ and economic $\left(\mathrm{X}_{2}\right)$ variables through social responsibility $\left(\mathrm{X}_{3}\right)$ variables is $34.90 \%$.

For the intervening variables (mediating variables), from the statistical analysis, it is known that the most influential variables are: Charismatic variable $\left(\mathrm{X}_{1}\right)$ through social responsibility $\left(\mathrm{X}_{3}\right)$ to $\mathrm{CE}(\mathrm{Y})$ is 28.77\%; and Economic variable $\left(\mathrm{X}_{2}\right)$ through social responsibility $\left(\mathrm{X}_{3}\right)$ to $\mathrm{CE}(\mathrm{Y})$ is $18.31 \%$. Based on these findings, the leadership practiced by Nyai in CE in the pesantren can be classified into three leadership models: charismatic, economic, and social responsibility models. The charismatic model is a leadership model that emphasizes personal charisma as a leader in managing and leading the pesantren. Meanwhile, the economic model is a leadership model that emphasizes economic factors to strengthen leadership. The social 
responsibility model is a leadership model that emphasizes the social responsibility of the community, which is reflected in the behavior of people who care about social activities. Table 2 shows the charismatic, economic, and social responsibility leadership models practiced by Nyai's leadership in pesantren.

Table 2. Analysis of descriptive research

\begin{tabular}{|c|c|c|}
\hline No & Data coverage & Interpretation/code \\
\hline 3 & $\begin{array}{l}\text { Orientation, time allocation, responsibility, social control, response structuring, participation, } \\
\text { connection, and idealism }\end{array}$ & Social responsibility model \\
\hline
\end{tabular}

The characteristics of Nyai's leadership with a charismatic model as shown in Figure 2 in the pesantren are reflected in the attitude of trust, delegation, togetherness, enthusiasm, respect, religious obedience, obedience, and community spirituality towards the pesantren leadership. All of this is a driving force that emerges from a charismatic leadership model, allowing people to have concern for the pesantren. Figure 2 shows $40 \%$ of Nyai's leadership model is charismatic in the form of trust; the rest is spirit (16\%), togetherness $(10 \%)$, spirituality $(9 \%)$, respect $(8 \%)$, obeying $(7 \%)$, religiosity $(5 \%)$, and delegate $(5 \%)$.

The characteristics of Nyai's leadership with an economic model as shown in Figure 3 in the pesantren are reflected in the ability to encourage and activate awareness for alms, raise concerns, encourage investment in the hereafter, encourage funding, building facilities, logistics, and attention to santri with a low-income family background (needy and poor). These things become the driving force that emerges from an economic leadership model, allowing people to have concern for the pesantren. Figure 3 shows $44 \%$ of economically Nyai's leadership model in the form of logistics, the remaining building facilities (27\%), funding (20\%), investment in the hereafter $(5 \%)$; the rest is a concern, almsgiving, and the conditions of the poor, respectively (1\%).

The characteristics of Nyai's leadership with the social responsibility model in the pesantren are reflected in the ability to encourage and realize orientation, time allocation, responsibility, social control, response structuring, participation, connection, and idealism. These things are the driving force that emerges from the leadership model of social responsibility, allowing people to have concern for the pesantren. Figure 4 shows $38 \%$ of Nyai's leadership model in terms of social responsibility in the form of responsibility, social control (13\%), orientation (12\%), time allocation (9\%), participation (9\%), connection (8\%), response structuring $(7 \%)$, and idealism $(4 \%)$.

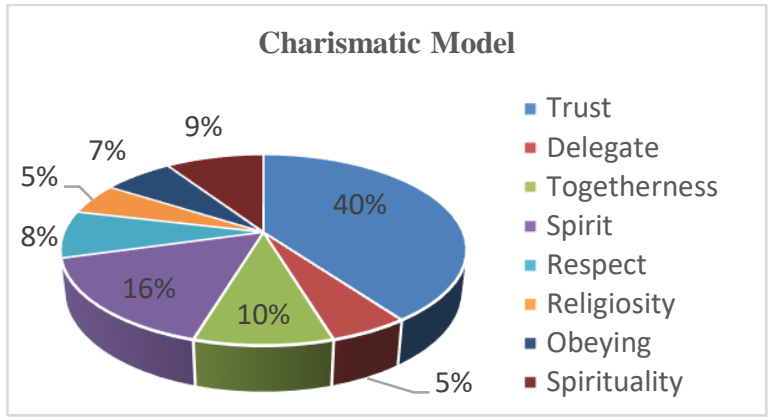

Figure 2. Charismatic models

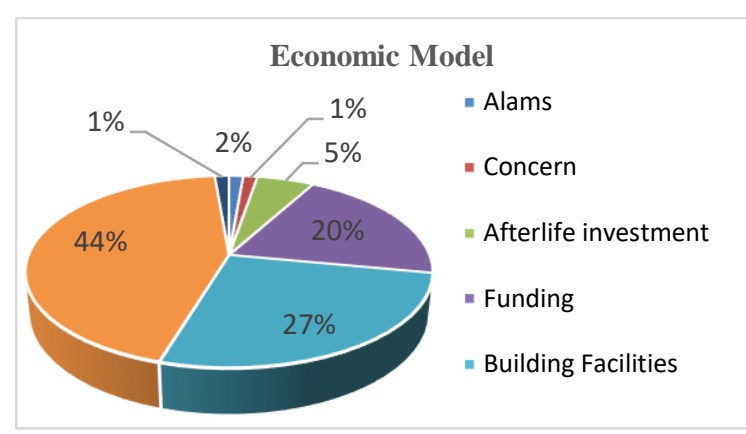

Figure 3. Economic models

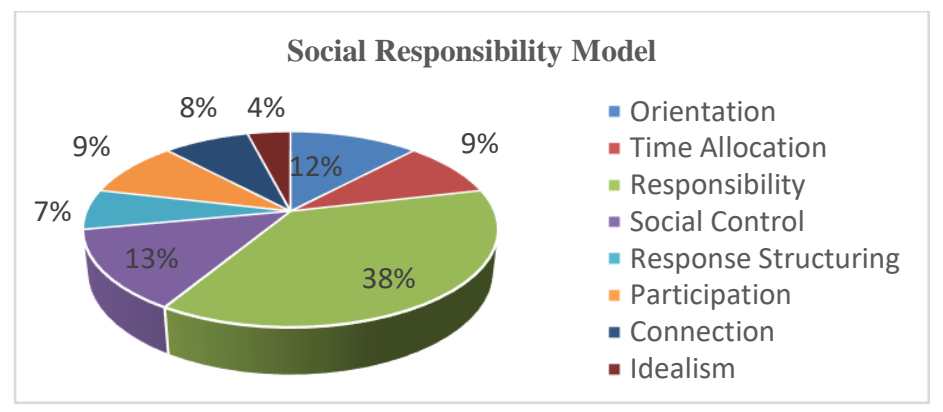

Figure 4. Social responsibility models 


\subsection{Discussion}

Nyai's leadership model in the context of community empowerment in the pesantren shows a significant effect both partially and simultaneously. The leadership models offered are the charismatic model, economic model, and social responsibility model. The charismatic model value is measured from trust, delegate, togetherness, spirit, respect, religiosity, obeying, and spirituality. The economic model value is calculated from alms, concern, afterlife investment, funding, building facilities, logistics, and the poor and destitute, while the social responsibility model value is measured from orientation, time allocation, responsibility, social control, response structuring, participation, and connection and idealism.

From these three Nyai's leadership models, several studies indicated that Nyai's leadership was dominated by charismatic leadership type [8], [14], [35]. Even from the research, Hidayah and Arifin have shown the type of Nyai's leadership to preserve the Kitab Kuning (traditional Islamic manuscripts) as evidenced by the dominance of charismatic and democratic types [6]. Sosik stated that charismatic leadership considers examples of behavioral models through the leader's words and deeds to be a key determinant of charismatic relationships [23]. Therefore, community empowerment research in the pesantren needs to consider behavioral models like trust, delegate, togetherness, spirit, respect, religiosity, obeying, and spirituality. Previous studies proved that the charismatic leadership model is essential in encouraging community empowerment in pesantren situations [6], [29], [30]. The pesantren leaders' charisma is the driving force for the emergence of public interest and attention towards the pesantren and the empowerment of the pesantren [36].

Concerning the economic model, Huis, et al. stated that society is empowered when it has strength, including power, cognitive, psychological, economic, and political [21]. Therefore, economic model research empowering the community needs to consider five aspects; power, cognitive, psychological, economic, and political to be alms, concern, afterlife investment, funding, building facilities, logistics, and the poor and destitute can run as expected in the pesantren. According to Sianipar, et al., this model can only be done if the leader believes that the community shares common interests, concerns, and identities [25]. That is why Sianipar et al. explained empowerment to build relationships of strength and competence of a person, use nature, and take proactive action on change and social policies. He further said that community empowerment is a process of developing and strengthening the ability to participate in sustainable community development [25]. To make that happen, several researchers suggested that the leadership of the pesantren should not only be fixated on leader figures but be more creative in developing the pesantren's economic program [7], [9]. Thus, it needs the creativity of the pesantren leadership to develop economic status in the pesantren, which also affects society's economy [37]-[39].

The pesantren economic leadership model is needed to strengthen the pesantren, especially from the aspect of empowerment. From existing research, it is known that this is only possible and can be done if pesantren leaders can build relationship strength and personal competence, use of resources, and proactive action and social policies. Creativity is the keyword in the development of the pesantren economic program.

The social responsibility model is illustrated by the value of orientation, time allocation, responsibility, social control, response structuring, participation, connection, and idealism. Hidayah and Arifin described that the success of women's leadership is influenced by dominant factors they are social, cultural, and political supports [6]. Even, Harvey complemented that with this responsiveness, determination, and creativity, Nyai's leadership built religious authority and pesantren's development [40].

In the social responsibility model, building values and factors that can influence social responsibility is essential in empowering the community. Therefore, the values and factors that can foster social responsibility must continue to be promoted by the pesantren's leadership. Moreover, Nyai, as the leader of the pesantren, is a person who has religious authority and is the spearhead of the future of the pesantren.

The discussion about community empowerment based on Nyai's leadership models has been constructed as models in the pesantren. Community empowerment is significantly affected by the application of Nyai's leadership model in the pesantren. Therefore, Sianipar, et al. state empowerment is expected to be the primary goal of developing the pesantren. Empowerment encourages and attracts all participation of the pesantren residents to change the pesantren's world so that it can be recognized from the outside. Sianipar, et al. stated that community empowerment has proven to be a practical approach to solving various community problems [25]. The aspects offered from each of Nyai's leadership models are essential to empower the pesantren community. These aspects increase public understanding and awareness to contribute to the development of the pesantren.

The study's findings demonstrate Antonakis theory, which states that charismatic leadership considers examples of behavioral models through the leader's words and deeds to be critical determinants of charismatic relationships [41]. It is reasonable that this research suggested the triple models (charismatic, economic, and social responsibility) in empowering community in leading pesantren at Ainul Yakin. It also shows that the theory of Cogliser, et al. that the spread of responsibility and member activity will help to a 
higher level of collective performance [24]. Thus, the effectiveness of Nyai's leadership needs to consider the existence of charisma, build economic factors as strengthening, and spread social responsibility to the community to build community empowerment in the pesantren in a sustainable manner for the development of the pesantren.

\section{CONCLUSION}

Based on the ten hypotheses explained, all indicate that the variables, either partially or simultaneously, significantly affect the community empowerment variable. This means that the three Nyai's leadership models in this study influence and contribute to community empowerment to support the pesantren's activities and programs. This can be seen in the three Nyai's leadership models; they are charismatic model characterized by community trust, economic model by community assistance in the form of logistics, and social responsibility model by community responsibility for the pesantren. Therefore, charismatic, economic, and social responsibility models of Nyai's leadership can be used as a reference in effective community empowerment in the pesantren.

Based on the findings of Nyai's leadership model applied in the pesantren, it is significantly able to empower the community. Therefore, it is vital to maintain these three Nyai's leadership models. However, it should be noted here that each leadership model has both advantages and disadvantages. It would be ideal for review, understanding, and mastery of various leadership models that occur through the Pesantren leadership process. Every time problems arise from the Nyai leadership model; problems can be solved using multiple leadership models, including charismatic, economic, and social responsibility models. It is also recommended for further study to take another example of pesantren in which the Nyai has a strategic position in community empowerment. It is also recommended for further study to take another example of pesantren in which Nyai has strategic position in community empowerment.

\section{REFERENCES}

[1] C.-M. Hefner, "Models of achievement: Muslim girls and religious authority in a modernist Islamic boarding school in Indonesia," Asian Stud. Rev., vol. 40, no. 4, pp. 564-582, 2016, doi: 10.1080/10357823.2016.1229266.

[2] M. T. Lopes Cardozo and E. Srimulyani, "Analysing the spectrum of female education leaders' agency in Islamic boarding schools in post-conflict Aceh, Indonesia," Gend. Educ., pp. 1-17, 2018, doi: 10.1080/09540253.2018.1544361.

[3] H. M. Marks and S. M. Printy, "Principal leadership and school performance: An integration of transformational and instructional leadership,” Educ. Adm. Q., vol. 39, no. 3, pp. 370-397, 2003, doi: 10.1177/0013161X03253412.

[4] J. Cerrato and E. Cifre, "Gender inequality in household chores and work-family conflict," Front. Psychol., vol. 9, pp. 1-11, Aug. 2018, doi: 10.3389/fpsyg.2018.01330.

[5] K. Kusmana, "Pesantren and Local Female Leadership in Modern Indonesia," TARBIYAH J. Educ. Muslim Soc., vol. 6, no. 1, pp. 23-34, 2019, doi: 10.15408/tjems.v6i1.8919.

[6] S. N. Hidayah and A. Arifi, "Women in Islamic Education Management: Learning from Pesantren Practices," Ulumuna, vol. 21, no. 1, pp. 129-150, 2017, doi: 10.20414/ujis.v21i1.1178.

[7] E. A. Rahayu and N. J. Faraz, "The Transformational Leadership of the Female Leader in Pesantren," Walisongo J. Penelit. Sos. Keagamaan, vol. 27, no. 2, pp. 299-332, 2019, doi: 10.21580/ws.27.2.4735.

[8] S. Hernawati, "The Kiai's Moderate Leadership Model in Improving the Quality of Educational Services," TAWASUT, vol. 3, no. 1, pp. 1-24, 2015, doi: 10.31942/ta.v3i1.1288

[9] S. Muflichah, "The Charisma Leadership Style of Kyai Haji Arwani Amin The founder of Yanbuul Quran Pesantren, Kudus," JICSA J. Islam. Civiliz. Southeast Asia, vol. 3, no. 1, pp. 61-81, 2014.

[10] M. Muhaemin, "The Mode of Leadership in a Traditional Islamic Boarding School," JICSA J. Islam. Civiliz. Southeast Asia, vol. 3, no. 1, pp. 61-104, 2014.

[11] B. Budiwiranto, "Pesantren and participatory development: the case of the Pesantren Maslakul Huda of Kajen, Pati, Central Java,” J. Indones. Islam, vol. 3, no. 2, pp. 267-296, 2009, doi: 10.15642/JIIS.2009.3.2.267-296.

[12] M. Elfira, "Slipping into The Shadows of Kyai's Figures: Women Participation in Indonesian Pesantren's Web of Power," Int. Rev. Humanit. Stud., vol. 4, no. 2, pp. 689-694, 2019, doi: 10.7454/irhs.v4i2.175.

[13] S. Chusniyah and M. Y. Alimi, "Nyai Dadah: The Elasticity of Gender Roles and Life History of Pesantren Woman Leader," Komunitas Int. J. Indones. Soc. Cult., vol. 7, no. 1, pp. 112-117, 2015, doi: 10.15294/komunitas.v7i1.3602.

[14] M. Syukri, Gender Equality in Indonesian New Developmental State: The Case of the New Participatory Village Governance. Jakarta: SMERU Research Institute, 2021.

[15] G. Laverack, "An identification and interpretation of the organizational aspects of community empowerment," Community Dev. J., vol. 36, no. 2, pp. 134-145, 2001, doi: 10.1093/cdj/36.2.134

[16] A. Y. Pratama and S. Sariffuddin, "Community-Based Disaster Management: A Lesson Learned from Community Emergency Response Management in Banyumas, Indonesia," in IOP Conference Series: Earth and Environmental Science, 2018, vol. 123, no. 1, pp. 1-10, doi: 10.1088/1755-1315/123/1/012003. 
[17] L. B. Cattaneo and A. R. Chapman, "The process of empowerment: A model for use in research and practice," Am. Psychol., vol. 65, no. 7, pp. 646-59, 2010, doi: 10.1037/a0018854.

[18] D. Adamson and R. Bromiley, "Community empowerment: learning from practice in community regeneration," Int. J. Public Sect. Manag., vol. 26, no. 3, pp. 190-202, 2013, doi: 10.1108/IJPSM-08-2011-0105.

[19] Iskandarini, "The impact of entrepreneurial barrier toward entrepreneurial intention for decreasing unemployment through community empowerment," Procedia-Soc. Behav. Sci., vol. 115, pp. 166-174, 2014, doi: 10.1016/j.sbspro.2014.02.425.

[20] G. Maheshwari and R. Nayak, "Women leadership in Vietnamese higher education institutions: An exploratory study on barriers and enablers for career enhancement," Educ. Manag. Adm. Leadersh., pp. 1-18, 2020, doi: $10.1177 / 1741143220945700$.

[21] M. A. Huis, N. Hansen, S. Otten, and R. Lensink, "A three-dimensional model of women's empowerment: Implications in the field of microfinance and future directions," Front. Psychol., vol. 8, no. 1678, pp. 1-14, 2017, doi: $10.3389 /$ fpsyg.2017.01678.

[22] B. Michaelis, R. Stegmaier, and K. Sonntag, "Affective commitment to change and innovation implementation behavior: The role of charismatic leadership and employees' trust in top management," J. Change Manag., vol. 9, no. 4, pp. 399-417, 2009, doi: 10.1080/14697010903360608.

[23] J. J. Sosik, "The role of personal values in the charismatic leadership of corporate managers: A model and preliminary field study," Leadersh. Q., vol. 16, no. 2, pp. 221-244, 2005, doi: 10.1016/j.leaqua.2005.01.002.

[24] C. C. Cogliser, W. L. Gardner, M. B. Gavin, and J. C. Broberg, "Big five personality factors and leader emergence in virtual teams: Relationships with team trustworthiness, member performance contributions, and team performance," Group Organ. Manag., vol. 37, no. 6, pp. 752-784, 2012, doi: 10.1177/1059601112464266.

[25] C. P. M. Sianipar, G. Yudoko, A. Adhiutama, and K. Dowaki, "Community empowerment through appropriate technology: Sustaining the sustainable development," Procedia Environ. Sci., vol. 17, pp. 1007-1016, 2013, doi: 10.1016/j.proenv.2013.02.120.

[26] Z. Dhofier, "The Pesantren Tradition: A Study of the Role of the Kyai in the Maintenance of the Traditional Ideology of Islam in Java," Thesis, Australian National University, 1980, doi: 10.25911/5d74e363a6ded.

[27] R. A. Lukens-Bull, "Two sides of the same coin: Modernity and tradition in Islamic education in Indonesia," Anthropol. Educ. Q., vol. 32, no. 3, pp. 350-372, 2001, doi: 10.1525/aeq.2001.32.3.350.

[28] C. N. Hashim and H. Langgulung, "Islamic religious curriculum in Muslim countries: The experiences of Indonesia and Malaysia," Bull. Educ. Res., vol. 30, no. 1, pp. 1-19, 2008.

[29] M. V. Bruinessen, "Kitab Kuning: Books in Arabic Script Used in the Pesantren Milieu: Comments on a New Collection in the KITLV Library," Bijdragen Tot de Taal-, Land-En Volkenkunde, vol. 146, no. 2/3, pp. 226-69, 1990. [Online]. Available: http://www.jstor.org/stable/27864122.

[30] M. Ritonga, S. Purnamasari, M. Budiarti, A. Lahmi, T. Nurdianto, and S. Zulfida, "The Management of Arabic Language and Yellow Book Curriculum Planning at Islamic Boarding School in Respond to the Freedom to Learn Education System," J. Manag. Inf. Decis. Sci., vol. 24, Special Issue 1, pp. 1-10, 2021, [Online]. Available: https://www.abacademies.org/abstract/the-management-of-arabic-language-and-the-yellow-book-curriculumplanning-at-islamic-boarding-schools-in-respond-to-the--11729.html.

[31] S. Ma'arif, "Education as a Foundation of Humanity: Learning from the Pedagogy of Pesantren in Indonesia," $J$. Soc. Stud. Educ. Res., vol. 9, no. 2, pp. 104-123, 2018.

[32] U. Husna and M. Thohir, "Religious Moderation as a New Approach to Learning Islamic Religious Education in Schools," Nadwa J. Pendidik. Islam, vol. 14, no. 1, pp. 199-222, 2020, doi: 10.21580/nw.2020.14.1.5766.

[33] T. Rocco, L. Bliss, S. G. S. Gallagher, A. P. A. Pérez, and P. Prado, "Taking the next step: Mixed methods taking the next step: Mixed methods research in organizational systems research in organizational systems," Inf. Technol. Learn. Perform. J., vol. 21, no. 1, pp. 19-29, 2003.

[34] M. B. Miles, A. M. Huberman, and J. Saldana, Qualitative data analysis: A methods sourcebook, SAGE Publications, 2014.

[35] H. Jannah and R. Ida, "Nyai Madura: Representation of Female Religious Leaders in Contemporary Indonesia," Space Cult. India, vol. 7, no. 1, pp. 240-249, 2019, doi: 10.20896/saci.v7i1.408.

[36] N. A. R. Alam, "Strengthening Leadership Culture (The Role of Kyai in Indonesian Pesantren)," -Ta'dib, vol. 13, no. 1, pp. 5-17, 2018, doi: 10.21111/at-tadib.v13i1.1986.

[37] A. Bawono, "Creative Economic Development of Pesantren," Shirkah J. Econ. Bus., vol. 3, no. 1, pp. 25-48, 2019, 10.22515/shirkah.v3i1.180.

[38] F. Febriyanti, I. Affandi, and E. Danial, "Model Economic Development of Civics in Character Formation Plus Entrepreneurial Behavior-Based Self-Reliance in the Pesantren," in Annual Civic Education Conference (ACEC 2018), 2018, pp. 315-319, doi: 10.2991/acec-18.2018.73.

[39] S. Kholifah, "Gender Bias on Foucault's concept of panopticon in understanding the structure of pesantren (Islamic boarding school) in Indonesia," J. Teach. Educ., vol. 2, no. 1, pp. 105-122, 2013.

[40] A. Harvey, "A dramaturgical analysis of charismatic leader discourse," J. Organ. Chang. Manag., vol. 14, no. 3, pp. 253-265, Jan. 2001, doi: 10.1108/09534810110394877.

[41] R. Mittal, "Charismatic and Transformational Leadership Styles: A Cross-Cultural Perspective," Int. J. Bus. Manag., vol. 10, no. 3, pp. 26-33, 2015, doi: 10.5539/ijbm.v10n3p26. 